\title{
Implementasi Audit Operasional dalam Prinsip Transparansi dan Akuntabilitas pada Kantor Kelurahan Baurung Kecamatan Banggae Timur Kabupaten Majene
}

\author{
Warka Syachbrani ${ }^{1}$,Sitti Mujahida Baharuddin ${ }^{2}$ \\ Akuntansi ${ }^{1}$, Manajemen ${ }^{2}$, Sekolah Tinggi Ilmu Ekonomi \\ AMKOP Makassar \\ Email: warka.syachbrani@stieamkop.ac.id ${ }^{1}$, sittimujahida.baharuddin@stieamkop.ac.id²
}

(Diterima: 5 Agustus 2019; direvisi: 25 Agustus 2019; dipublikasikan: Oktober 2019 )

(7) (5) (C2019 -Bongaya Journal for Research in Management STIEM Bongaya. Ini adalah artikel dengan akses terbuka dibawah licenci CC BY-NC-4.0 (https://creativecommons.org/licenses/by-nc/4.0/).

\begin{abstract}
This study aims to find empirical evidence of how the implementation of Operational Audit on the Principles of Transparency and Accountability in Government agencies.This research used the observation and documentation method or content analysis method. Research data collection was carried out at the apparatus of Kelurahan Baurung, Kecamatan Banggae Barat, Kabupaten Majene. The results of this study founded that the existence of an operational audit in accordance with applicable audit standards and in accordance with the operational audit stages, would be able to improve the principles of transparency and accountability in realizing good governance in the publicsector.
\end{abstract}

\section{Keywords: Operational Audit; Public Sector FinancialManagement}

\begin{abstract}
Abstrak: Penelitian ini bertujuan untuk mencari bukti empirik bagaimana Implementasi Audit Operasional pada Prinsip Transparansi dan Akuntabilitas pada instansi Pemerintah. Penelitian ini menggunakan metode observasi dan analisis dokumen content analysis. Pengumpulan data penelitian dilakukan pada aparatur Kelurahan Baurung Kecamatan Banggae Timur Kabupaten Majene. Hasil penelitian ini menemukan bahwa adanya pelaksanaan audit operasional yang sesuai dengan standar audit yang berlaku dan sesuai dengan tahap-tahap audit operasional,maka akan dapat meningkatkan prinsip transparansi dan akuntabilitas dalam mewujudkan good governance pada sektorpublik.
\end{abstract}

Kata kunci: Audit Operasional; Manajemen Keuangan SektorPublik

\section{PENDAHULUAN}

Selama ini sektor publik tidak luput dari tudingan sebagai sarang korupsi, kolusi, nepotisme, inefisiensi dan sumber pemborosan negara. Keluhan " birokrat tidak mampu berbisnis " ditujukan untuk mengkritik buruknya kinerja intansi-instansi sektor publik. Pemerintah sebagai salah satu organisasi sector public pun tidak luput dari tudingan ini. Organisasi sektor publik pemerintah merupakan

lembaga yang menjalankan roda pemerintahan yang sumber legitimasinya berasal dari masyarakat.Oleh karena itu, kepercayaan yang diberikan oleh masyarakat kepada penyelenggara pemerintahan haruslah diimbangi dengan adanya pemerintahan yang bersih.

Pemerintahan yang bersih atau good governance ditandai dengan tiga pilar utamayang merupakan elemen dasar yang saling berkaitan (Prajogo, 2001). Ketiga elemen dasar tersebut adalah partisipasi, transparansi dan akuntabilitas. Suatu pemerintahan yang baik harus membuka pintu yang seluas-luasnya agar semua pihak yang terkait dalam pemerintahan tersebut dapat 

berperan serta atau berpartisipasi secara aktif, jalannya pemerintahan harus diselenggarakan secara transparan dan pelaksanaan pemerintahan tersebut harus dapat dipertanggungjawabkan. Dalam bahasa akuntansi, akuntabilitas (kemampuan memberikan pertanggungjawaban) merupakan dasar dari pelaporan keuangan (Wilopo, 2001). Pelaporan keuangan pemerintah tersebut memegang peran yang penting agar dapat memenuhi tugas pemerintahan yang dapat dipertanggung jawabkan kepada masyarakat dalam suatu masyarakat yang demokratis.

Dalam negara demokrasi, "pelaporan keuangan yang transparan" merupakan sesuatu yang dituntut oleh rakyat kepada pemerintahnya. Sebaliknya, dalam negara demokrasi, pemerintah berkewajiban memberikan laporan keuangan yang transparan kepada rakyat. Pemerintah demokratis harus bertanggung jawab atas integritas, kinerja dan kepengurusan, sehingga pemerintah harus menyediakan informasi yang berguna untuk menaksir akuntabilitas serta membantu dalam pengambilan keputusan ekonomi, sosial dan politik. Pemerintah adalah entitas pelapor (reporting entity) yang harus membuat laporan keuangan dengan beberapa pertimbangan berikut (Partono, 2000) : 1) Pemerintah menguasai dan mengendalikan sumber-sumber yang signifikan, 2) Penggunaan sumber-sumber tersebut oleh pemerintah dapat berdampak luas terhadap kesejahteraan ekonomi rakyat, 3) Terdapat pemisahan antara manajemen dan pemilikan sumber-sumber tersebut

Laporan keuangan yang dihasilkan oleh organisasi sektor publik pemerintah merupakan instrumen utama untuk menciptakan akuntabilitas sektor publik (Mardiasmo, 2002). Akuntabilitas mengacu pada kewajiban perseorangan, suatu kelompok atau suatu organisasi yang diasumsikan harus melaksanaka kewenangan dan/atau pemenuhan tanggung jawab. Kewajiban tersebut meliputi :1) Answering, usaha untuk memberikan penjelasan atau justifikasi untuk pelaksanaan dan / atau pemenuhan

tanggungjawab, $\quad$ 2) Reporting, pelaporan hasil atas pelaksanaan dan / atau pemenuhan, 3) Producing, asumsi kewajiban atas hasil yang dicapai

Adanya tuntutan yang semakin besar terhadap pelaksanaan akuntabilitas publik menimbulkan implikasi bagi manajemen sektor publik untuk memberikan informasi kepada publik, salah satunya melalui informasi akuntansi yang berupa laporan keuangan. Dilihat dari sisi internal organisasi, laporan keuangan sektor publik merupakan alat pengendalian dan evaluasi kinerja manajerial dan organisasi. Sedangkandari sisi eksternal, laporan keuangan merupakan alat pertanggungjawaban kepada publik dan sebagai dasar untuk pengambilan keputusan. Menurut GASB, tujuan laporan keuangan sektor publik adalah (Mardiasmo, 2002): 1) Mempertanggungjawabkan pelaksanaan fungsinya (Demonstrating Accountability), 2) Melaporkan hasil operasi (Reporting Operating Result), 3) Melaporkan kondisi keuangan (Reporting Financial Condition), 4) Melaporkan sumber daya jangka panjang (Reporting Long Live Resources).

Seiring dengan munculnya tuntutan dari masyarakat agar organisasi sektor publik mempertahankan kualitas, profesionalisme dan akuntabilitas publik serta value for money dalam menjalankan aktivitasnya serta untuk menjamin dilakukannya pertanggungjawaban publik oleh organisasi sektor publik, maka diperlukan audit terhadap organisasi sektor publik tersebut. Audit yang dilakukan tidak hanya terbatas pada audit keuangan dan kepatuhan, namun perlu diperluas dengan melakukan audit terhadap kinerja organisasi sektor publik tersebut.

Berdasarkan latar belakang di atas, maka peneliti tertarik untuk melaksanakan penelitian ini. Penelitian ini menguji implementasi audit operasional dalam rangka transparansi dan akuntabilitas pada Kantor Kelurahan Baurung Kecamatan Banggae Timur Kabupaten Majene.

\section{TEORI DAN LITERATUR REVIEW}

\section{a. AuditOperasional}

Ada beberapa pengertian mengenai audit operasional menurut para ahli. Menurut Tunggal (2008), "Audit operasional merupakan audit atas operasi yang dilaksanakan dari sudut pandang manajemenn untuk menilai ekonomi, efisiensi,dan efektifitas dari setiap dan seluruh operasi,terbatas hanya pada keinginan manajemen".

Menurut Bayangkara (2013) adalah sebagai berikut: "Rancangan secara sistemastis untuk mengaudit aktivitas-aktivitas, programprogram, yang diselenggarakan, atau sebagian dari entitas yang bias diaudit untuk menilai dan melaporkan apakah sumber daya dan dana telah digunakan secara efisien, serta apakah tujuan dari 


\section{Syachbrani \& Baharuddin, Implementasi Audit Operasionaldalam Prinsip Transparansi dan Akuntabilitas pada Kantor Kelurahan Baurung Kecamatan Banggae Timur Kabupaten Majene $\mid$}

program dan aktivitas yang telah direncanakan dapat tercapai dan tidak melanggar ketentuan aturan dan kebijakan yang telah ditetapkan perusahaan.

Menurut Tunggal (2008), "pemeriksaan operasional merupakan suatu penilaian dari organisasi manajerial dan efisiensi dari suatu perasahaan, departemen, atau setiap entitas dan sub entitas yang dapat di audit". Sedangkan General Accounting Office (GAO) di Amerika Serikat mendefinisikan pemeriksaan operasional sebagai auditing yang menentukan : 1) Apakah entitas mengelola dan menggunakan sumber dayanya (seperti personil, kekayaan, ruangan) secara ekonomis dan efisien 2) Penyebab dari ketidakefektivan atau praktik yang tidak ekonomis, dan 3) Apakah entitas telah menaati hukum dan peraturan yang berhubungan dengan masalah ekonomis dan efisiensi.

Menurut Guy, Alderman, \&Winters (2002) menyatakan bahwa Audit operasional merupakan penelaahan atas prosedur dan metode operasi entitas untuk menentukan tingkat efisiensi dan efektivitasnya. Pada kesimpulan tentang audit operasional, rekomendasi yang umumnya diberikan adalah memperbaiki prosedur. Audit operasional kadang-kadang disebut sebagai audit kinerja, audit manajemen, atau audit

komprehensif. Secara international, istilah yang sering digunakan untuk audit operasional adalah audit nilai uang (value-for-moneyauditing)

Disampingitu,dalam bukunya,Boynton, Johnson, \& Kell (2004) menyatakanbahwa "Audit operasional adalah suatu proses sistematis yang mengevaluasi efektifitas, efisiensi, dan kehematan operasi organisasi yang berada dalam pengendalian manajemen serta melaporkan kepada orang-orang yang tepat hasil-hasil evaluasi tersebut beserta rekomendasi perbaikan" Berdasarkan definisi di atas dapat disimpulkan bahwa Audit Operasional yaitu suatu proses sistematis untuk menilai kegiatan operasional perusahaan apakah sudah dilakukan secara efektif, efisien, dan ekonomis serta memberikan rekomendasi perbaikan kepada pihak manajemen sehingga keberlangsungan kegiatan perusahaan dapat berjalan denganbaik.

\section{Struktur dan Ruang Lingkup Audit Operasional}

Menurut Guy, Alderman, \&Winters (2002), struktur umum dari audit operasional adalah proses lima tahap yaitu:
Sebelum memulai suatu audit operasional,auditor (atau konsultan) terlebih dahulu harus mengenali kegiatan atau fungsi yang sedang di audit. Untuk melaksanakan hal ini, auditor menelaah latar belakang informasi, tujuan, struktur organisasi, dan pengendalian kegiatan atau fungsi yang sedang di audit, serta menentukan hubungannya dengan entitas secara keseluruhan.

\section{2) Survei}

Selama tahap survei dari audit operasional, yang lebih dikenal sebagai survei pendahuluan (preliminary survey), auditor harus berusaha untuk mengidentifikasi bidang masalah dan bidang penting yang menjadi kunci keberhasilan kegiatan atau fungsi yang sedang di audit.

\section{3) PengembanganProgram}

Pada awalnya auditor menyusun program pekerjaan, berdasarkan tujuan audit, yangmerinci pengujian dan analisis yang harus dilaksanakan atas bidang-bidang yang dianggap "penting" dari hasil survei pendahuluan. Disamping itu, auditor juga menjadwalkan kegiatan kerja, menugaskan personel yang sesuai, menentukan keterlibatan personel lainnya dalam penugasan, serta menelaah kertas kerjaaudit.

\section{4) PelaksanaanAudit}

Pelaksanaan audit merupakan tahap utama dari audit operasional. Auditor melaksanakan prosedur audit yang telah ditentukan dalam program audit untuk mengumpulkan bukti-bukti, melakukan analisis, menarik kesimpulan, dan mengembangkan rekomendasi. Selama melakukan pekerjaan lapangan, auditor harus menyelesaikan setiap langkah audit yang spesifik dan mencapai tujuan audit secara keseluruhan untuk mengukur efektivitas, efisiensi, dan ekonomis.

\section{5) Pelaporan}

Tahap pelaporan merupakan tahap yang penting bagi keberhasilan keseluruhan audit operasional yang dilakukan.

Laporan audit operasional pada umumnya mengandung dua unsur utama,yaitu(1) tujuan penugasan, ruang lingkup, dan pendekatan serta, (2) temuan-temuan khusus dan rekomendasi. Ruang lingkup audit operasional lebih difokuskan pada fungsi produksi suatu perusahaan yang berarti melakukan pemeriksaan segi operasional suatu perusahaan.

1) Pengenalan. 
Ruang lingkup audit keuangan tradisional lebih ditekankan pada accounting control yang terdiri dari :

1) Mengamankanperusahaan

2) Menguji ketelitian dan kebenaran data akuntansi.

Cara yang digunakan untuk mencapai tujuan diatas,yaitu dengan menggunakan laporan keuangan. Sedangkan audit operasional bertujuan untuk mengetahui apakah cara-cara yang digunakan dalam perusahaan sudah berjalan denganlancar.

Jadi, audit operasional lebih ditekankan pada administrative control yang terdiri dari :

1) Menunjang efektivitasperusahaan

2) Menilai ketaatan pada kebijakan yang telah digariskan olehpimpinan.

Persamaan dari keduanya adalah auditor sama-sama melakukan perbandingan antara standar atau kriteria tertentu dengan melaksanakan yang ditemuinya.

Ruang lingkup audit operasionalmenurut Mulyadi (2002) adalah : "Pembatasan terhadap ruang lingkup audit operasional, mempunyai akibat terhadap jumlah dan kompetensi bukti yang dapat dikumpulkan oleh auditor dari suatu perusahaan". Jadi, disimpulkan bahwa ruang lingkup audit operasional adalah tinjauan kebijakan operasinya, perencanaan, praktik (kinerja), hasil dari kegiatan dalam mencapai tujuan perusahaan. Oleh karena itu, audit dilakukan tidak terbatas hanya pada masalah akuntansinya saja, melainkan di segala bidang yang berhubungan dengan perusahan seperti kepegawaian.

\section{Tujuan Dan Manfaat Audit Operasional}

Tujuan utama audit operasional adalah mengevaluasi efektifitas dan efisiensi organisasi, namun audit operasional juga dapat menjangkau aspek yang ketiga, yaitu ekonomisasi. Evaluasi ekonomi adalah pemeriksaan atas biaya dan manfaat dari suatu kebijakan atau prosedur. Dalam konteks audit operasional, evaluasi ekonomi merupakan pertimbangan jangka panjang tentang apakah manfaat kebijakan atau prosedur lebih besar daripada biayanya.

Menurut Guy, Alderman, \& Winters (2002), audit operasional biasanya dirancang untuk memenuhi satu atau lebih tujuan berikut :
1) Menilai Kinerja. Setiap audit operasional meliputi penilaian kinerja organisasi yang ditelaah. Penilaian kinerja dilakukan dengan membandingkan kegiatan organisasi dengan

(a) tujuan, seperti kebijakan, standar, dan sasaran organisasi yang ditetapkan manajemen atau pihak yang menugaskan, serta dengan (b) kriteria penilaian lain yang sesuai.

2) Mengidentifikasi Peluang Perbaikan. Peningkatan efektivitas, efisiensi, dan ekonomi merupakan kategori yang luas dari pengklasifikasian sebagian besar perbaikan. Auditor dapat mengidentifikasi peluang perbaikan tertentu dengan mewawancari individu (apakah dari dalam atau dari luar organisasi), mengobservasi operasi,menelaah laporan masa lalu atau masa berjalan, mempelajari transaksi, membandingkan dengan standar industri, menggunakan pertimbangan profesional berdasarkan pengalaman, atau menggunakan sarana dan cara lain yangsesuai.

3) Mengembangkan Rekomendasi untuk Perbaikan atau Tindakan Lebih Lanjut. Sifat dan luas rekomendasi akan berkembang secara beragam selama pelaksanaan audit operasional.

Menurut Agus (2004) ada empat tujuan audit operasional yaitu:

1) Untuk menilai kinerja (performance) dari manajemen dan berbagai fungsi dalam perusahaan.

2) Untuk menilai apakah persediaan perusahaan telah digunakan secara efisien dan ekonomis.

3) Untuk menilai efektifitas perusahaan dalam mencapai tujuan yang telah ditetapkan oleh manajemenpuncak.

4) Untuk memberikan rekomendasirekomendasi kepada manajemen puncak untuk memperbaiki kelemahan-kelemahan yang terdapat dalam penerapan sistem pengendalian internal dan prosedur operasional perusahaan dalam rangka meningkatkan efisiensi, keekonomisan dan efektifitas dari kegiatan operasionaal perusahaan.

Sejalan dengan perkembangan perusahaan, manajemen akan dihadapkan dengan berbagai masalah dalam memonitor semua dearah kegiatan yang menjadi tanggung jawabnya. Hal ini menimbulkan pemikiran bahwa apabila manajemen ingin dapat beroperasi dengan baik tentu mereka memerlukan berbagai bentuk peringatan dini (early warning system) yang dapat 
Syachbrani \& Baharuddin, Implementasi Audit Operasionaldalam Prinsip Transparansi dan Akuntabilitas pada Kantor Kelurahan Baurung Kecamatan Banggae Timur Kabupaten Majene |

mendeteksi berbagai masalah yang merugikan dan berbagai kesempatan untuk pengembangan dan penyempurnaan. Salah satu cara yang digunakan oleh para manajer tersebut adalah dengan menggunakan audit operasional.

Secara ringkas dapat disimpulkan bahwa audit operasional dilakukan untuk mengevaluasi tingkat efisiensi dan efektivitas pelaksanaan aktivitas suatu organisasi. Audit operasional mengidentifikasi timbulnya penyelewengan dan penyimpangan yang terjadi dan kemudian membuat laporan yang berisi rekomendasi tindakan perbaikan selanjutnya.Audit operasional merupakan salah satu alat pengendalian yang membantu dalam mengelola perusahaan dengan penggunaan sumber daya yang ada dalam pencapaian tujuan perusahaan dengan efektif dan efisien.

Adapun manfaat yang dapat diperoleh dengan adanya audit operasional menurut Tunggal (2008) adalah:

1) Memberi informasi operasi yang relevan dan tepat waktu untukpengambilankeputusan

2) Membantu manajemen dalam mengevaluasi catatan, laporan-laporan danpengendalian.

3) Memastikan ketaatan terhadap kebijakan manajerial yang ditetapkan, rencana-rencana, prosedur serta persyaratan peraturan pemerintah.

4) Mengidentifikasi area masalah potensialpada tahap dini untuk menentukan tindakan preventif yang akandiambil.

5) Menilai ekonomisasi dan efisiensi penggunaan sumber daya termasuk memperkecilpemborosan.

6) Menilai efektivitas dalam mencapai tujuan dansasaranperusahaanyangtelahditetapkan.

7) Menyediakan tempat pelatihan untuk personil dalam seluruh fase operasiperusahaan.

\section{Jenis Audit Operasional}

Arens \& Loebbecke (2008) membagi audit operasional menjadi tiga jenis yaitu : "1. Functional Audit 2. Organizational Audit 3. Special Assigment." Dari kutipan diatas dapat diuraikan sebagai berikut :

1) Functional Audit

Fungsi merupakan suatu alat penggolangan kegiatan suatu perusahaan, seperti fungsi penerimaan kas atau fungsi produksi. Seperti yangtersiratdalamnamanya, auditfungsional berkaitan dengan sebuah fungsi atau lebih dalam suatu organisasi. Keunggulan audit fungsional adalah menungkinkan adanya spesialisasi oleh auditor. Auditor dapatlebih efisien memakai seluruh waktu mereka untuk memeriksa dalam bidang itu. Kekurangan audit fungsional adalah tidak dapat dievaluasinya fungsi yang saling berkaitan didalam organisasi.

2) Organizational Audit

Audit operasional atas suatu organisasi menyangkut keseluruhan unit organisasi, seperti departemen, cabang, atau anak perusahaan. Penekanan dalam suatu audit organisasi adalah seberapa efisien dan efektif fungsi-fungsi yang saling berinteraksi.

3) Special Assigment

Penugasan audit operasional khusus timbul atas permintaan manajemen. Ada banyak variasi dalam audit seperti itu. Contohcontohnya mencakup penentuan penyebab tidak efektifnya system PDE, penyelidikan kemungkinan kecurangan dalam suatu divisi, dan membuat rekomendasi untukmengurangi biaya produksi suatubarang.

\section{Kriteria Audit Operasional}

Salah satu kesulitan yang dihadapi dalam audit operasional adalah menentukan kriteria untuk mengevaluasi apakan efisiensi dan efektivitas telah tercapai. Di dalam audit keuangan, Standar Akuntansi Keuangan merupakan kriteria umum untuk mengevaluasi kewajaran penyajian laporan keuangan, dalam audit operasional tidak ada kriteria standar yang dapat digunakan sebagai pedoman.

Menurut Arens \& Loebbecke (2008), ada beberapa sumber kriteria yang dapat digunakan :

1) Kinerja Historis (Historical Performance) Historical Performance merupakan kriteria yangdidasarkanpadahasilaktualdariperiode (atau audit) sebelumnya. Hal inidilaksanakan untuk membandingkan apakah prestai kerja periode sekarang lebih baik atau lebih buruk dibandingkan dengan prestasi kerja periode sebelumnya.Keuntungan penggunaan kriteria ini adalah tidak dapat memberikan gambaran apakah perusahaan tersebut benar-benar berjalan dengan baik atausebaliknya.

2) Kinerja yang dapat diperbandingkan (Benchmarking). Benchmarking merupakan kriteria yang ditetapkan berdasarkan hasil yang dicapai oleh entitas yang sama dalam organisasi secara keseluruhan atau diluar organisasi. Data prestasi dari entitas dibandingkan merupakan sumber yang baik untuk kriteria dalam benchmarking.

3) Standar Rekayasa (Engineered Standards) Engineerd Standards merupakan kriteria 
yang ditetapkan berdasarkan standar teknik, seperti time and motion study untuk menentukan banyaknya output yang harus diproduksi. Penggunaan krteria ini efektif untuk menyelesaikan berbagai masalah operasional yang penting, tetapi pembuatan kriteria ini memerlukan keahlian yangkhusus sehingga memakan banyak waktu dan biaya yang cukuptinggi.

Diskusi dan Kesepakatan (Discussion and Agreement). Discussion and Agreement merupakan kriteria yang ditetapkan berdasarkan hasil diskusi dan kesepakatan bersama antara pihak manajemen dan entitas yang akan diaudit, auditor operasional, dan pihak yang akan menerimalaporanhasilauditoperasional.Kriteria ini umum digunakan karena pembuatan kriteria yang lalu seringkali sulit dan membutuhkan biaya yang tinggi.

\section{Tahap-Tahap Audit Operasional}

Auditor operasional perlu memiliki suatu tahapan tugas untuk pedoman baginya dalam bekerja.Tanpaadanyatahapanyangtersusunbaik pemeriksa akan banyak menghadapai kesulitan dalam melaksanakan pekerjaan mengingat bahwa struktur perusahaan atau pun kegiatan sekarang ini sudah semakin maju danrumit.

Ada beberapa tahapan yang harus dilakukan dalam audit manajemen. Secara garis besar dapat dikelompokkan menjadi lima, menurut Bayangkara (2013) yaitu:

1) Audit Pendahuluan. Audit pendahuluan dilakukan untuk mendapatkan informasi latar belakang terhadap objek yang diaudit. Pada tahap audit ini juga dilakukan penelaahan terhadap berbagai peraturan, ketentuan dan kebijakan berkaitan dengan aktivitas yang diaudit serta menganalisis berbagai informasi yang telah diperoleh untuk mengidentifikasi hal-hal yang potensial mengandung kelemahan pada perusahaan yangdiaudit.

2) Review dan Pengujian Pengendalian Manajemen. Pada tahap ini auditor melakukan review dan pengujian terhadap pengendalian manajemen objek audit dengan tujuan untuk menilai efektivitaspengendalian manajemen dalam mendukung pencapaian tujuanperusahaan.

3) Audit Rinci / Lanjutan. Pada tahap iniauditor melakukan pengumpulan bukti yang cukup dan kompeten untuk mendukung tujuan audit yang telah ditentukan. Pada tahap inijuga dilakukan pengembangan temuan untuk mencari keterkaitan antara satutemuan dengan temuan yang lain dalam menguji permasalahan yang berkaitan dengan tujuan audit.

4) Pelaporan. Tahapan ini bertujuan untuk mengkomunikasikan hasil audit termasuk rekomendasi yang diberikan kepada berbagai pihak yang berkepentingan. Hal ini penting untuk meyakinkan pihak manajemen (objek audit) tentang keabsahan hasil audit dan mendorong pihak-pihak yang berwenang untuk melakukan perbaikan terhadap berbagai kelemahan yangditemukan.

Tindak Lanjut Sebagai tahap akhir dari audit manajemen, tindak lanjut bertujuan untuk mendorong pihak-pihak yang berwenang untuk melaksanakan tindak lanjut (perbaikan) sesuai dengan rekomendasi yang diberikan

\section{Efisisensi dan Efektivitas Audit Operasional}

Efisiensi dan efektivitas audit operasional dikenal sebagai audit yang berkonsentrasi pada efektivitas dan efisiensi organisasi. Efektivitas mengukur seberapa berhasil suatu organisasi mencapai tujuan dan sasarannya. Efisiensi mengukur seberapa baik suatu entitas menggunakan sumberdayanya dalam mencapai tujuannya. Sebagai contoh di Amerika Serikat, seorang auditor dapat memeriksa Badan Federal untuk menentukan apakah badan tersebut telah mencapai tujuannya seperti yang ditetapkan oleh Kongres (efektivitas) dan menggunakan sumber daya keuangannya secara benar (efisiensi). Pembahasan mengenai ekonomisasi, efisiensi, dan efektivitas akan lebih mudah dipahami jika dibahas dalam kerangka Input - Proses - Output. Dalam sub bab ini,lebih difokuskan pada efisiensi dan efektivitas.

1) Efisiensi

Efisiensi berhubungan dengan bagaimana perusahaan melakukan operasinya, sehingga dicapai optimalisasi penggunaan sumber daya yang dimiliki. Efisiensi berhubungan dengan metode kerja (operasi). Dalam hubungannya dengan konsep input-prosesoutput, efisiensi adalah rasio antar output dan input. Seberapa besar output yang dihasilkan dengan

menggunakan sejumlah tertentu input yang dimiliki perusahaan. Metode kerja yang baik akan dapat memandu proses operasi berjalan dengan mengoptimalkan penggunaan sumber daya yang dimiliki perusahaan. Jadi, efisiensi merupakan ukuran proses yang menghubungkan antara input dan output dalam operasional perusahaan. Jadi, efisiensi merupakan ukuran proses yang 
Syachbrani \& Baharuddin, Implementasi Audit Operasionaldalam Prinsip Transparansi dan Akuntabilitas pada Kantor Kelurahan Baurung Kecamatan Banggae Timur Kabupaten Majene |

menghubungkan antara input dan output dalam operasional perusahaan (Bayangkara, 2013).

Menurut Anthony \& Govindarajan (2005): Efisiensi adalah rasio output terhadap input, atau jumlah output per unit input. Pusat Tanggung Jawab A lebih efisien daripada Pusat Tanggung Jawab B jika (1) menggunakan jumlah sumber daya yang lebih sedikit dari pada Pusat Tanggung Jawab B, namun memproduksi jumlah output yang sama, atau (2) menggunakan jumlah sumber daya yang sama namun memproduksi jumlah output yang lebihbesar.

2) Efektivitas.

Dibandingkan dengan efisiensi, yang ditentukan oleh hubungan antara input dan output, efektivitas ditentukan oleh huungan antara output yang dihasilkan oleh suatu pusat tanggang jawab dengan tujuannya. Semakin besar output yang dikonstribusikan terhadap tujuan, maka semakin efektiflah unittersebut. Efektivitas cenderung dinyatakan dalam istilah-istilah yang subjektif dan nonalitis, seperti kinerja kampus A adalah yang terbaik, tetapi kampus B telah agak menurun dalam tahuntahun terakhir (Anthony \& Govindarajan,2005).

Menurut Anthony \& Govindarajan (2005): Efisiensi dan efektivitas berkaitan satu sama lain, setiap pusat tanggung jawab harus efektif dan efisien dimana organisasi harus mencapai tujuannya dengan cara yang optimal. Suatu pusat tanggung jawab yang menjalankan tugasnya dengan konsumsi terendah atas sumber daya, mungkin akan efisien, tetapi jika output yang dihasilkannya gagal dalam memberikan kontribusi yang memadai pada pencapaian citacita organisasi, maka pusat tanggung jawab tersebut tidaklah efektif.

\section{Keterbatasan Audit Operasional}

Meskipun audit operasional memiliki banyak manfaat, audit ini juga memiliki banyak keterbatasan. Menurut Reider (2002) audit operasional memiliki banyak keterbatasan karena tidak dapat menyelesaikna semua masalah yang timbul didalam organisasi. Ada tiga faktor yang membatasi audit operasional yaitu :

1) Waktu

2) Keahlian yangdiperlukan

3) Biaya

Waktumerupakanfaktoryangmembatasi audit operasional untuk mencapai tujuan dan manfaat audit operasional. Hal inidisebkan karena auditor harus dengan segera memberikan informasi kepada manajemen mengenai masalah organisasi yang timbul dan cara-cara yang tepat untuk mengatasi masalah tersebut. Audit operasional harus dilaksanakan secara teratur untuk menjamin bahwa masalah-masalah organisasi yang penting tidak menjado kronis dalam perusahaan.

Keterbatasan dalam audit operasional yang lain adalah kurangnya keahlian audit operasinal terhadap teknik audit dan objek yang diperiksa. Tidak mungkin bagi seorang auditor untuk ahli disegala bidang bisnis. Untuk mengatasi keterbatasan ini perlu pendidikan dan pelatihan bagi auditor operasional.

Biaya juga merupakan salah satu faktor pembatas bagi audit operasional. Auditor operasional selalu mencoba untuk menghemat uang kliennnya.Keterbatasan biaya yang tersedia ini mengharuskan auditor untuk menentukan segala prioritas auditnya. Masalah organisasi yang mengancam keberadaan organisasi perlu mendapatkan prioritas audit

\section{b. Transparansi}

Transparansi merupakan keadaan dimana setiap orang dapat mengetahui proses pembuatan dan pengambilan keputusan di pemerintahan umum. Menurut UU No.28 Tahun 2000 tentang penyelenggaraan pemerintah yang bersih dan bebas korupsi, kolusi, dan Nepotisme, azas keterbukaan (transparansi) dalam penyelenggaraan pemerintah daerah azas untuk membuka diri terhadap hak masyarakat untuk memperoleh informasi yang benar, jujur dan diskriminatif tentang penyelnggaraan pemerintahan daerah dengan tetap memeperhatikan perlindunag hak asasi pribadi, golongan dan rahasianegara.

Pengertian transparansi menurut UNDP adalah sebagai berikut: "Tersedianya informasi secara bebas dan dapat diakses secara langsung (directly accessible) kepada pihakpihak yang terkena dampak oleh suatu pelaksanaan keputusan, kemudian informasi disediakan dengan isi yang mudah untuk dipahami, sistem yang transparan memiliki prosedur yang jelas dalam pengambilan keputusan publik. Kemudian adanya saluran komunikasi informasi antara stakeholders danbirokrat".

Menurut Mardiasmo (2002) pengertian transparansi adalah "Keterbukaan pemerintah dalam membuat kebijaksanaan kebijaksanaan keuangan daerah sehinggadapat 


\section{1 | Bongaya Journal of Research in Management Vol.2 No. 2 Oktober 2019}

\author{
diketahui dan diawasi oleh DPRD dan \\ masyarakat."
}

Dari beberapa pengertian di atas dapat di simpulkan bahwa transparansi adalah suatu keadaan atau sifat yang mudah dilihat dengan jelas. Jika dikaitkan dengan konteks penyelenggaraan urusan publik, transparasni adalah suatu kondisi dimana masyarakat mengetahui apa-apa yang terjadi dan dilakukan oleh pemerintah termasuk berbagai prosedur, serta keputusan-keputusan yang diambil oleh pemerintah dalam pelaksanaan urusan publik. Dalam hal ini peran pemerintah adalah membuka diri terhadap hak masyarakat untuk memeperoleh informasi yang benar, jujur dan tidak diskriminatif tentang penyelenggaran pemerintahdaerah.

Menurut UNDP, Transparansi akan tercapai dengan cara membagi atau menyebarkan informasi dan bertindak dengan cara terbuka. Hal tersebut berarti memperbolehkan para stakeholder untuk memperoleh informasi.Sistem yang transparan memeiliki prosedur yang jelas dalam pengambilan keputusan publik dan adanya saluran komunikasi yang terbuka antara berbagai stakeholders dengan aksebilitasi yang baik terhadap sumber informasi. Transparansi dibangun berdasarkan kebebasan untuk memperoleh informasi. Proses kelembagaan, dan informasi tersedia secara langsung terutama bagui pihak-pihak yangberkepentingan.

Keterbukaan informasi publik telah di atur dalam UU No.14 Tahun 2008 adalah sebagai berikut : "Bahwa Informasi adalah keterangan, pernyataan, gagasan, dan tanda-tanda yang mengandung nilai, makna, dan pesan, baik data, fakta maupun penjelasannya yang dapat dilihat, didengar, dan dibaca yang disajikan dalam berbagai kemasan dan format sesuai."

$$
\text { Dengan perkembangan teknologi }
$$

informasi dan komunikasi, kemudian hak memperoleh informasi merupakan hak asasi manusia dan keterbukaan Informasi Publik merupakan salah satu ciri penting negara demokratis yang menjunjung tinggi kedaulatan rakyat untuk mewujudkan penyelenggaraan negara yang baik. keterbukaan Informasi Publik merupakan sarana dalam mengoptimalkan pengawasan publik terhadap penyelenggaraan negara dan badan publik lainnya dan segala sesuatu yang berakibat pada kepentingan publik. Bahwa pengelolaan Informasi Publik merupakan salah satu upaya untuk mengembangkan masyarakat informasi

\section{Karakteristik Transparansi}

Mardiasmo (2002) dalam bukunya menjelaskan, karakteristik Transparansi yang harus dipenuhi meliputi sebagai berikut :

1) Informativeness(informatif)

Pemberian arus informasi, berita, penjelasan mekanisme, prosedur, data, fakta kepada stakeholders yang membutuhkan informasi secara jelas dan akurat.

2) Openess(keterbukaan).

Keterbukaan Informasi Publik memberi hak kepada setiap orang untuk memperoleh informasidenganmengaksesdatayangadadi badan publik, dan menegaskan bahwa setiap informasi publik itu harus bersifat terbuka dan dapat diakses oleh setiap pengguna informasi publik, selain dari informasi yang dikecualikan yang diatur oleh UndangUndang.

3) Disclosure(pengungkapan)

Pengungkapan kepada masyarakat atau publik (stakeholders) atas aktivitas dan kinerjafinansial

\section{c. Akuntabilitas}

Menurut Herawati \& Halim (2008), Akuntabilitas publik merupakan pemberian informasi dan pengungkapan atas aktivitas dan kinerja keuangan pemerintah kepada pihak-pihak yang berkepentingan. Dengan informasi dan pengungkapan tersebut, baik pemerintah pusat maupun pemerintah daerah harus mau dan mampu menjadi subyek pemberi informasi atas aktivitas dan kinerja keuangan yang diperlukan secara akurat, relevan, tepat waktu, konsisten dan dapat dipercaya. Pemberian informasi dan pengungkapan kinerja keuangan ini adalah dalam rangka pemenuhan hak- hak masyarakat, yaitu hak untuk mendapatkan informasi, hak untuk diperhatikan aspirasi dan pendapatnya, hak diberi penjelasan, dan hak menuntut pertanggungjawaban.

Menurut Rasul (2002) akuntabilitas adalah kemampuan memberi jawaban kepada otoritas yang lebih tinggi atas tindakan seseorang atau sekelompok orang terhadap masyarakat luas dalam suatu organisasi. Akuntabilitas yakni para pengambil keputusan dalam organisasi sektor publik, swasta serta masyarakat madani memiliki pertanggungjawaban (akuntabilitas) kepada publik (masyarakat umum) sebagaimana halnya pada pemilik kepentingan (Sumarsono, 2009).

Mahsun (2011) dalam bukunya Pengukuran Kinerja Sektor Publik menjelaskan bahwa aspek akuntabilitas publik merupakan 


\section{Syachbrani \& Baharuddin, Implementasi Audit Operasionaldalam Prinsip Transparansi dan Akuntabilitas pada Kantor Kelurahan Baurung Kecamatan Banggae Timur Kabupaten Majene $\mid$}

salah satu dari tiga aspek yang tercakup dalam anggaran sektor publik. Akuntabilitas adalah pertanggungjawaban kepada publik atas setiap aktivitas yang dilakukan.

Menurut UNDP, akuntabilitas adalah evaluasi terhadap proses pelaksanaan kegiatan/kinerja organisasi untuk dapat dipertanggungjawabkan serta sebagai umpan balik bagi pimpinan organisasi untuk dapat lebih meningkatkan kinerja organisasi pada masa yang akan datang. Akuntabilitas dapat diperoleh melalui:

1) Usaha untuk membuat para aparat pemerintahan mampu bertanggungjawab untuk setiap perilaku pemerintah dan responsive pada identitas dimana mereka memperolehkewenangan

2) Penetapan kriteria untuk mengukur performan aparat pemerintahan serta penetapan mekanisme untuk menjamin bahwa standar telahterpenuhi.

Dalam usaha untuk mewujudkan tujuan manajemen Pemerintahan, maka dalam proses pengelolaan Kelurahan sangat diperlukan adanya akuntabilitas agar semua kegiatan pemerintahan desa dapat berhasil. Akuntabilitas sendiri merupakan prinsip pertanggungjawaban publik yang berarti bahwa proses penganggaran keuangan mulai dari proses perencanaan, penyusunan, dan pelaksanaan harus benar-benar dapat dilaporkan dan dipertanggungjawabkan kepada masyarakat (Syachbrani, 2013).

Masyarakat tidak hanya memiliki hak untuk mengetahui anggaran tersebut tetapi juga berhak untuk menuntut pertanggungjawaban atas rencana ataupun pelaksanaan anggaran tersebut. Oleh karena itu, dengan adanya akuntabilitas dalam pengelolaan dana desa maka penyerapan anggaran dapat terjadi secara maksimal karena mendapat pengawasan langsung dari masyarakat.

\section{Indikator Akuntabilitas}

Menurut Lalolo (2003) akuntabilitas dalam penyelenggaraan pemerintahan terdiri dari beberapa elemen antara lain :

1) Adanya akses publik terhadap laporan yang telahdibuat;

2) Penjelasan dan pembenaran terhadap tindakanpemerintah;

3) Penjelasan harus dilakukan dalam sebuah forumterbuka;

4) Aktor harus memiliki kewajiban untukhadir.

Disebutkan oleh Shafritz \& Russel (1997), indikator akuntabilitas adalah sebagai berikut :
1) Proses pembuatan sebuah keputusan yang dibuat secara tertulis, tersedia bagi wargadan memenuhistandaradministrasiyangberlaku.

2) Akurasi dan kelengkapan informasi yang berhubungan dengan caracara mencapai sasaran suatuprogram;

3) Kejelasan dari tujuan yang ingindicapai;

4) Kelayakan dan konsistensi dari target operasional;

5) Sistem informasi manajemen dan monitoring hasil.

Menurut (Mardiasmo, 2002), anggaran sektor publik mempunyai beberapa fungsi utama, yaitu: (1) alat perencanaan, (2) alatpengendalian, (3) alat kebijakan fiskal, (4) alat politik, (5) alat koordinasi dan komunikasi, (6) alat penilaian kinerja, (7) alat motivasi, dan (8) alat menciptakan ruang publik. Herawati \& Halim (2008), penyusunan anggaran dapat dikatakan baik apabila memenuhi persyaratan:

(1) berdasarkan program, (2) berdasarkan pusat pertanggungjawaban dan (3) sebagai alat perencanaan danpengendalian.

\section{METODE}

\section{a. Desain Penelitian}

Penelitian ini didesain sebagai penelitian deskriptif dengan pendekatan kualitatif. Penelitian ini dilakukan untuk mengetahui nilai masing-masing variabel, baik satu variabel atau lebih sifatnya independen tanpa membuat hubungan maupun perbandingan dengan varibel yang lain (Sujarweni, 2015). Penelitian ini di lakukan di Kantor Kelurahan Baurung, Kecamatan Banggae Timur, Kabupaten Majene, Sulawesi Barat dengan waktu penelitian selama 2bulan.

Dalam pelaksanaan penelitian jenis data yang digunakan, yaitu data primer dan data sekunder. Data primer dalam penelitianini adalah data yang diperoleh dari hasil pengamatan dan wawancara langsung kepada pihak-pihak yang terkait dengan pengelolaan keuangan. Data sekunder dalam penelitian ini adalah data yang diperoleh dari dokumen-dokumen kelurahan dari tahun 2015 sampai2018.

Data dikumpulan dengan menggunakan teknik pengumpulan data observasi, wawancara, dan dokumentasi. Dari hasil pengumpulan data tersebut, data kemudian dianalisis dengan menggunakan metode analisis data kualitatif model Content Analysis, dan selanjutnya ditarik kesimpulan. 


\section{b. Fokus Penelitian dan Deskripsi Fokus}

Fokus penelitian ini adalah Pelaksanaan Audit Operasional pada institusi Pemerintahan berdasarkan Peraturan Perundang-undangan yang berlaku. Adapun yang dimaksud dengan Audit Operasional adalah rangkaian aktivitas audit atas operasi yang dilaksanakan Pemerintah dari sudut pandang manajemen untuk menilai ekonomi, efisiensi, dan efektifitas dari setiap dan seluruh kegiatan.

\section{c. Teknik Analisis Data}

Proses analisis data dilakukan secara terus menerus dimulai dengan menelaan seluruh datayangtersediadariberbagaisumber,yaitudari wawancara, pengamatan yang sudah dituliskan dalam catatan lapangan,dokumen dan sebagainya sampai dengan penarikan kesimpulan. Didalam melakukan analiis data peneliti mengacu kepada beberapa tahapan yang dijelaskan Miles dan Huberman yang dikutip oleh (Moleong (2011) terdiri dari beberapa tahapan antaralain:

1) Pengumpulan informasi melalui wawancara terhadap key informan yang compatible terhadap penelitian kemudian observasi langsung ke lapangan untuk menunjang penelitian yang dilakukan agar mendapatkan sumber data yang diharapkan.

2) Reduksi data (data reduction) yaitu proses pemilihan, pemusatan perhatian pada penyederhanaan, transformasi data kasar yang muncul dari catatan-catatandi lapangan selama meneliti, tujuan diadakan transkrip data (transformasi data) untu kmemilih informasi mana yang dianggap sesuai dan tidak sesuai dengan masalah yang menjadi pusat penelitian di lapangan.

3) Penyajian data (Data Display) yaitu kegiatan sekumpulan informasi dalam bentuk naratif, grafik jaringan, table dan bagan yang bertujuan mempertajam pemahaman penelitian terhadap informasi yang dipilih kemudian disajikan dalam tabel ataupun uraian penjelasan.

4) Pada tahap akhir adalah penarikan kesimpulan atau verifikasi (conclution drawing/verification), yang mencari artipolapola penjelasan, konfigurasi yang mungkin, alur sebab akibat dari proposisi. Penarikan kesimpulan dilakukan secara cermat dengan melakukan verifikasi berupa tinjauan ulang pada catatan-catatan di lapangan sehingga data dapat di ujivaliditasnya.

\section{HASIL DAN PEMBAHASAN a. Pengenalan Lokasi Penelitian}

Kelurahan adalah pembagian wilayah administratif di Indonesia di bawah kecamatan. Kelurahan merupakan wilayah kerja lurah sebagai perangkat daerah kabupaten atau kota. Kelurahan dipimpin oleh seorang lurah yang berstatus sebagai Pegawai Negeri Sipil.

Kelurahan merupakan unit pemerintahan terkecil setingkat dengan desa. Berbeda dengan desa, kelurahan memiliki hak mengatur wilayahnya lebih terbatas.

Dalam perkembangannya, sebuah desa dapat diubah statusnya menjadi kelurahan, atau sebaliknya.

Kelurahan Baurung merupakan salahsatu wilayah administratif yang berada di Kecamatan Banggae Kabupaten Majene, Sulawesi Barat. Kelurahan ini terletak pada sisi sebelah timur Pusat Pemerintahan KabupatenMajene.

\section{b. Pengujian Pelaksanaan Audit Operasional}

\section{Analisis terhadap Audit Operasional}

Kegiatan operasional pada kantor Kelurahan Baurung secara teknis diawasi oleh Inspektorat Pemerintah Daerah Kabupaten Majene. Audit yang merupakan satuan pengawasan internal Pemerintahan yang bertugas melakukan evaluasi efektivitas pengendalian internal secara obyektif dan memberikan konsultasi atas pelaksanaan kegiatan operasionalnya.

Dalam melaksanakan tugasnya, auditor inspektorat mengacu pada Standar Audit Intern Pemerintah Indonesia. Inspektorat Kabupaten dipimpin oleh seorang Inspektur yang bertanggung jawab kepada Bupati.

Selama tahun 2014-2018, Inspektorat Kabupaten selalu melakukan aktivitas audit berdasarkan Advanced Risk Based Audit yang meliputi audit operasional dan audit khusus.

\section{Analisis terhadap Pengendalian Internal}

Sistem Pengendalian Internal Pemerintah (SPIP) yang diatur dalam Peraturan Pemerintah No 60 tahun 2008 mendefinisikan sistem pengendalian internal sebagai proses yang integral pada tindakandan kegiatan yang dilakukan secara terus menerus oleh pimpinan dan seluruh pegawai untuk memberikan keyakinan memadai atas tercapainya tujuan organisasi melalui kegiatan yang efektif dan efisien, keandalan pelaporan keuangan, pengamanan aset negara, dan

ketaatan terhadap peraturan perundangundangan. 
Syachbrani \& Baharuddin, Implementasi Audit Operasionaldalam Prinsip Transparansi dan Akuntabilitas pada Kantor Kelurahan Baurung Kecamatan Banggae Timur Kabupaten Majene |

Menurut Zamzami \& Faiz (2015) unsur Sistem Pengendalian Intern dalam Peraturan Pemerintah ini mengacu pada unsur Sistem Pengendalian Intern yang telah dipraktikkan di lingkungan pemerintahan di berbagai negara, yang meliputi:

1) Lingkungan Pengendalian, yaitu Pimpinan Instansi Pemerintah dan seluruh pegawai harus menciptakan dan memelihara lingkungan dalam keseluruhan organisasi yang menimbulkan perilaku positif dan mendukung terhadap pengendalian interndan manajemen yangsehat,

2) Penilaian Risiko, yaitu pengendalian intern harus memberikan penilaian atas risiko yang dihadapi unit organisasi baik dari luar maupun dari dalam,

3) Kegiatan Pengendalian, yaitu kegiatan pengendalian membantu memastikan bahwa arahan pimpinan Instansi Pemerintah dilaksanakan Kegiatan pengendalian harus efisien dan efektif dalam pencapaian tujuan organisasi.

4) Informasi dan Komunikasi, yaitu informasi harusdicatatdandilaporkankepadapimpinan Instansi Pemerintah dan pihak lain yang ditentukan. Informasi disajikan dalam suatu bentuk dan sarana tertentu serta tepat waktu sehingga memungkinkan pimpinan Instansi pemerintah melaksanakan pengendalian dan tanggungjawabnya,

5) Pemantauan yaitu pemantauan harus dapat menilai kualitas kinerja dari waktu ke waktu dan memastikan bahwa rekomendasi hasil audit dan review lainnya dapat segera ditindaklanjuti. Untuk memperkuat dan menunjang efektivitas penyelenggaraan Sistem Pengendalian Intern dilakukan pengawasan intern dan pembinaan penyelenggaraanSPIP.

Konsepsi pengendalian internal di sektor publik bertujuan untuk mencapai pengelolaan Keuanganpublikyangefektif,efisien,transparan, dan akuntabel (pasal 2 PP No 60 Tahun 2008). Keberadaan sistem pengendalian internal sangat penting bagi suatu institusi karena Pengendalian yang lemah akan mengakibatkan kerugian, skandal, kegagalan, bahkan kebangkrutan atau rusaknya reputasi. Jika risiko dibiarkan sajatanpa adanya media pengendali risiko, maka hal tersebut akan menjadi permasalahan institusi dalam mencapai tujuannya (Pickett,2003).

Analisis Lingkungan terhadap Pengendalian

Peneliti memandang lingkungan

pengendalian yang diterapkan di Kelurahan
Baurung cukup baik dan mendukung penerapan sistem pengendalian internal. Lingkungan pengendalian yang ada mencerminkan situasi yang dapat mendukung manajemen dalam menciptakan sistem pengendalian internal lembaga yang efektif yaitu:

a) Integritas dan NilaiEtika

Lurah telah menyusun kode etik bagi pegawai, baik PNS dan tenaga kontrak. Bentuk pelanggaran terkait dengan kode etik diproses berdasarkan aturan berlaku yang dikoordinasikan oleh Inspektorat Kabupaten.

b) Komitmen kepadaKompetensi

Kelurahan memiliki komitmen dalam mendorong pegawai untuk dapat melanjutkan pendidikan ke bidang yang lebih tinggi dan mengambil sertifikasi keahlian. Kebijakan ini berlakubagi PNS maupun tenaga honorer.Halini tercermin kedalam draf perencanaan Kelurahan dan komitmen Kabupaten Majene untuk meningkatkan kualitas pegawai dengan memberikan beasiswa agar pegawai dapat melanjutkan pendidikan.

c) Filosofi Manajemen dan GayaOperasi

Lurah mendukung dan mengembangan Struktur pengelolaan keuangan yang baik (pencatatan hingga pelaporan baik secara manual maupun terkomputerisasi) sehingga tercipta pola keterbukaan, efisiensi dan efektifitas dalam menjalankan aktivitas.

d) Struktur Organisasi

Struktur organisasi Kelurahan Baurung dirancang cukup fleksibel untuk menghadapi perubahan tugas pokok dan fungsi pimpinan dan pegawai.

e) Penetapan dari Otoritas dan Tanggung Jawab

Tanggung jawab dan pendelegasian

otoritas Kelurahan telah ditetapkan secara jelas \& tertulis pada masing-masing unit kerja. Wewenang diberikan kepada pegawai yang tepat sesuai dengan tingkat tanggung jawabnya dalam rangka pencapaian tujuan Kelurahan yang diberi wewenang mampu memahami wewenang dan tanggung jawab yang dimiliki dengan baik.

\section{Analisis terhadap Penilaian Resiko}

Penilaian risiko baik identifikasi risiko dan analisis risiko lebih sering dilakukan oleh Satuan Audit Internal yaitu disusun dalam mengidentifikasi dan menganaisis risiko secara menyeluruh di Kelurahan Baurung yang digunakan untuk pemilihan unit yang akan diaudit dengan memperhatikan risiko yang paling besar akan menjadi prioritas dalam penugasan audit. Beberapa catatan dalam evaluasi penilaian risiko adalah belum ada dokumentasi unit kerjadi 
lingkungan Kelurahan dalam melakukan penilaian risiko yang berisi mengenai pernyataan dan arahan yang spesifik, terukur, dapat dicapai, realistis, dan terikat waktu sehubungan dengan pengelolaan risiko yang dihadapi.

\section{Analisis terhadap Komunikasi dan Informasi}

Kelurahan Baurung telah memiliki informasi dan komunikasi berupa sistem anggaran, penatausahaan keuangan, dan akuntansi yang digunakan untuk pemrosesan transaksi untuk pengeluaran/penggunaan anggaran, pemrosesan sistem informasi dalam bentuk aplikasi anggaran yaitu SIMDA, aplikasiaplikasi sistem informasi keuangan untuk penatausahaan dalam pengajuan uang muka dan pembuatan pertanggung jawaban, aplikasi akuntansi yaitu untuk penyusunan laporan keuanganyangselanjutnyaakandikonsolidasikan keKabupaten,sertaaplikasiasset(SIMDABMD) yang digunakan untuk mencatat mutasi aset termasuk dalam penyusunan depresiasi aset.

Catatan yang sebaiknya diperbaiki dalam proses pengembangan sistem terintegrasi adalah proses kompilasi Laporan Keuangan Kabupaten Majene belum dilakukan secara otomatisasi melalui software akuntansi yang sudah ada,tetapi masih dilakukan secara manual dengan mempergunakan spreadsheet (Microsoft Excel) Proses kompilasi tersebut sangat rawan terhadap salah saji dengan pertimbangan volume datayang harus dikompilasi cukup besar dan rawan terhadapkesalahanyangdisebabkanolehmanusia (humanerror).

Analisis terhadap Aktifitas Pengendalian.

Evaluasi terhadap aktivitas pengendalian internal pada pengelolaan keuangan meliputi: a) Reviu pencapaian atas kinerja Kelurahan. Kelurahan melakukan review atas kinerja keuangantiapsemesteranyangbersamaandengan proses penyusun an anggaran tahunan dan RKAT Perubahan dalam Rapat Kerja Kabupaten, selain itu proses reviu juga dilakukan oleh fungsi legislatif.

b) PembinaanSDM.

c) Pemrosesan Informasi. Akses ke data/bukubuku/catatan/laporan di Kelurahan sudah dikendalikan oleh pihak-pihak sesuai dengan tugas kerjanya dan hanya staf yang ditunjuk mempunyai otoritas yang dapat mengaksesnya karena setiap pegawai sudah memiliki gambaran pekerjaan yangjelas.

d) PengendalianFisikAset/Sarana.Kebijakandan prosedur pengamanan fisik aset di Kelurahan telah disusun, diterapkan, dan dikomunikasikan kepada pegawai, hal ini ditunjukkandengan bahwa setiap unit kerja ada staf yang ditunjuk untuk menjalankan tugas sebaga pengelola barang dan bertanggung jawab kepada PPKAD, yang mengkoordinasikan untuk pengelolaan aset mulai dari pengadaan, pemeliharaan, dan pemanfaatan aset di seluruhSKPD.

e) Pemisahan tugas dan tanggung jawab sudah diterapkan. Adanya pemisahan antara bagian keuangan dengan bagian pengadaan, dan bagian akuntansi, hal ini penting dilakukan untuk meminimalisir risiko kesalahan dankecurangan.

f) Pembagian tugas dan tanggung jawab. Dalam penanganan suatu transaksi atau kejadian di Kelurahan sudah diatur sedemikian rupasehingga tidak ada perangkapan tugas terutama dalam otorisasi, persetujuan, pemrosesan, dan pencatatan, pembayaran atau penerimaan uang, reviu, dan pemeriksaan, misalnya dalam merealisasikan anggaran maka unit kerja harus mengajukan terlebih dahulu uang muka kerja dengan diotorisasi oleh atasan unit kerja yang mengajukan, kemudian PPKAD melalui sistem keuangan melakukan verifikasi kesesuaian anggaran, setelah itu jika sudah sesuai maka akan disenyetujui uang muka tersebut. Demikian pula sebaliknya pada saat menyusun pertanggung jawaban juga akan diverifikasi oleh PPKAD dan pada periode tertentu akan diperiksa oleh Inspektorat.

g) Transaksi atau kejadian yang sah yang dikerjakan oleh staf yang ditunjuk dengan merujuk pada RKAT unitkerja.

h) Pencatatan transaksi dan kejadian di klasifikasikan dan dicatat secara tepat sesuai dengan Bagan Akun Standar dan jenis kegiatan yang dilakukan, misal kegiatan pelayanan, kegiatan peningkatan layananan dan kegiatan lainnya. Secara umum pada aktivitas pengendalian sudah didokumentasikan dan diterapkan dengan jelas namun masih ditemukan transaksi penerimaan yang tidak disetor ke Rekening KasDaerah.

\section{Analisis terhadap Pemantauan}

Pemantauan yang telah dilakukan terdiri atas:a)Monitoringkegiatanyangsedangberjalan (ongoing monitoring) yaitu pengawasan secara langsung dan melekat dilakukan oleh atasan langsung yang ditunjukkan dengan adanya otorisasi untuk setiap transaksi mulai dari pengajuan dana sampai dengan pelaksanaan kegiatan termasuk dalam penyusunan laporan keuangan. Inspektorat Kabupaten secara rutin melakukan penugasan audit dan konsultasi pada unit kerja dilingkungan Kelurahan Baurung dan yang secaraperiodik. 
Syachbrani \& Baharuddin, Implementasi Audit Operasionaldalam Prinsip Transparansi dan Akuntabilitas pada Kantor Kelurahan Baurung Kecamatan Banggae Timur Kabupaten Majene |

b) Tindak lanjut atas temuan audit yaitu Kelurahan memiliki mekanisme untuk memastikan adanya penyelesaian atas temuan hasil audit dan review lainnya.Dari hasil audit BPK dan Inspektorat yang disampaikan hasilnya kepada Bupati, temuan-temuan yang berkaitan dengan Kelurahan, dilakukan monitoring tindak lanjut.

Dari hasil penelitian berdasarkan lima komponen pelaksanaan audit operasional sesuai SPIP (PP No 60 tahun 2008) dapat dipastikan bahwa Kelurahan Baurung tidak termasuk kelurahan yang melakukan kecurangan. Hasil auditoperasionalolehBPKtahun2017-2018juga

menunjukkan hasil yang sama. Apabila Kelurahan telah memenuhi komponen pengendalian internal sesuai SPIP maka dapat dijadikan indikasi pelaporan keuangan disajikan dengan baik dan terbebas dari kecurangan sebagaimana disimpulkan oleh Zamzami \& Faiz (2015) bahwa untuk dapat mengetahui secara pasti Institusi Pemerintah mana yang terindikasi melakukan kecurangan maka BPK dapat melakukan investigasi lebih mendalam.Meskipun demikian, penelitian ini menyarankan perlunya upaya perbaikan terstruktur dan sistematis atas peningkatan kapasitas SDM dalam menjalankan sistem, utamanya sistem akuntansi.

\section{SIMPULAN DAN SARAN}

Penelitian ini menemukan indikasi bahwa elemen-elemen sistem pengendalian internal yang diaplikasikan oleh Kelurahan Baurung cukup efektif dan mendukung praktik manajerial yang baik. Selain itu, prinsip pengelolaan yang transparan dan akuntabel sudah diterapkan dengan cukup baik. Akan tetapi pada beberapa aspek juga masihmengandung beberapa kelemahan untuk diperbaiki yaitu, meningkatkan kepatuhan terhadap standar prosedur yang telah disusun.

Hasil penelitian ini menemukan bahwa adanya pelaksanaan audit operasional yangsesuai dengan standar audit yang berlaku dan sesuai dengan tahap-tahap audit operasional, maka akan dapat meningkatkan prinsip transparansi dan akuntabilitas dalam mewujudkan good governance pada institusi sektor publik. Selanjutnya,penelitian ini memberikan kontribusi dalam peningkatan good governance sehingga visi, misi, dan tujuan pengelolaan Kelurahan dapat dicapai dengan efektif dan efisien. Persiapan secara serius atas sumber dayamanusia (SDM) dalam menjalankan sistemperlu dilakukan untuk meningkatkan efektifitas penerapan sistem akuntansi.

\section{DAFTAR RUJUKAN}

Agus, S. (2004). Auditing (Pemeriksaan Akuntan) oleh Kantor Akuntan Publik. Jakarta: Lembaga Penerbit Fakultas Ekonomi.

Anthony, R. N., \& Govindarajan, V. (2005). Management Control System: Sistem Pengendalian Manajemen. Jakarta: Salemba Empat.

Arens, A. A., \& Loebbecke, J. K. (2008). Auditing An Integrated Approach. New York: Prentice-Hall International Inc.

Bayangkara, I. (2013). Pengantar Manajemen: Prosedur dan Implementasi. Jakarta: Salemba Empat.

Boynton, W., Johnson, R., \& Kell, W. (2004). Modern Auditing 7th Edition. New Jersey, USA: John Wiley \& Sons.

Guy, D., Alderman, C., \&Winters, A. (2002). Auditing: Jilid 1. Jakarta: Erlangga.

Herawati, V., \& Halim, A. (2008). Peran Praktek Corporate Governance Sebagai Moderating Variabel Dari Pengukuran Earnings Management Terhadap Nilai Perusahaan. Simposium Nasional Akuntansi XI. Pontianak: IAI Kompartemen Akuntan Pendidik.

Lalolo, L. K. (2003). Indikator Alat Ukur Prinsip Akuntabilitas, Transparansi dan Partisipasi. Jakarta: Badan Perencanaan Pembangunan Nasional.

Mahsun, M. (2011). Pengukuran Kinerja Sektor Publik. Yogyakarta: Penerbit BPFE.

Mardiasmo. (2002). Akuntansi Sektor Publik. Yogyakarta: Penerbit Andi.

Moleong, L. J. (2011). Metode Penelitian Kualitatif (Edisi Revisi). Bandung: Remaja Rosda Karya.

Mulyadi. (2002). Auditing Buku 1 Edisi 6. Jakarta: Salemba Empat. 
Partono. (2000). Laporan Keuangan Pemerintah: Upaya Menuju Transparansi dan Akuntabilitas. Media Akuntansi Edisi 14.

Pickett, K. (2003). The Essential Handbook of Internal Auditing 2nd Edition. West Sussex: John Wiley \& Son.

Prajogo. (2001, Agustus). Perspektif Pemeriksa terhadap Implementasi Standar Akuntansi Keuangan. Jurnal Akuntansi dan Keuangan Sektor Publik, 02(02), 18.

Rasul, S. (2002). Pengintegrasian Sistem Akuntabilitas Kinerja dan Anggaran. Jakarta: Detail Rekod.

Reider, H. R. (2002). The Complete Guide To Operational Auditing. New York: John Wiley \& Son.

Shafritz, J. M., \& Russel, E. W. (1997). Introducing Public Administration. New York: Longman.

Sujarweni, V. W. (2015). Metode Penelitian Bisnis dan Ekonomi. Yogyakarta: Pustaka Baru Press.

Sumarsono, H. (2009). Analsis Kemandirian Otonomi Daerah. Jurnal Akuntansi Pemerintah, 1(1).

Syachbrani, W. (2013). Akuntansi dan Akuntabilitas Pemerintah Desa. Yogyakarta: Universitas Gadjah Mada.

Tunggal, A. W. (2008). Audit Manajemen. Jakarta: Rineka Cipta.

Wilopo. (2001, Juni). Faktor-faktor yang Menentukan Kualitas Audit pada Sektor Publik. Ventura, 4(1), 27-32.

Zamzami, F., \& Faiz, I. A. (2015, April).

Evaluasi Implementasi Sistem Pengendalia Internal: Studi Kasus pada Sebuah Perguruan Tinggi Negeri. Jurnal Akuntansi Multiparadigma (JAMAL), 6(1), 166-174. 